sents statistics of sixty cases taken consecutively from his case-book, in forty of which there was a choroiditis noted, and in many of the other twenty the opacity of the lens was so far advanced as to prevent a study of the fundus oculi.

I can recall five or six cases in which a preliminary iridectomy has been periormed, and the patients have waited from one to fifteen years for the cataract to become ripe; at the present time they are no nearer maturity, and in two or three cases the lens is clearer than at the time of the iridectomy.

Thomas ${ }^{15}$ and White ${ }^{16}$ each report a case in which after triturating the lens to hasten maturity, the opacity disappeared entirely.

Witvalsky ${ }^{18}$ has collected eighteen cases of spontaneous cure of senile cataract by absorption, reported within the past eight years, to which he adds two of his own and concludes that such cases are much more common than is generally supposed.

High degree of myopia has long been recognized as a predisposing cause of cataract-the same is true of glaucoma, the one can often be prevented by spectacles and the other cured by operation. While it is true that these are exceptional cases that we all recognize and act upon, is it not true that more of the cases of cataract if recognized earlier and studied carefully might be retarded or even cured? So many "cures" for cataract have been proposed by ignorant and unprincipled practitioners that any one proposing to treat incipient cataract is generally looked upon either as a fool or a knave. Consequently we have generally been contented to give the advice: "Wait until the cataract becomes ripe," and have not given these cases that honest study and close observation that we have many other diseases.

I do not believe that clinical observation will confirm Priestly Smith's" conclusions in all cases, "that senile cataract is entirely a local process and is not dependent on any disordered state of the general health."

In view of the preceding observations, may we not say that occasionally incipient cataracts under medical, hygienic, dietetic or local treatment do remain stationary or even entirely disappear and that the resources of our art looking toward this end have not been entirely exhausted?

In conclusion, I wish to suggest that in all cases of incipient cataract: 1, the urine should be examined chemically and microscopically; 2 , the general health should be carefully interrogated; 3 , all errors of refraction should be corrected; 4 , a careful examination of the fundus oculi should be made; 5 , that the patient receive such general and local treatment as may be suggested by the above inquiries; 6 , that a few carefully reported histories of cases from incipiency to maturity would be of more value than statis. ties of hundreds of successful operations; 7 , that if operative interference becomes necessary it should be instituted at the earliest possible moment before the general health becomes impaired, preferably by Knapp's ${ }^{19}$ method of peripheral capsulotomy, with an iridectomy either at the time of the operation or some time previously.

$$
\text { BIBLIOGRA PHY. }
$$

1 Aarriotte: Nouvelles Deconvertis sur le rue, Paris, $166 \mathrm{~s}$ 2 Boerhaave: de Morb Ocul Paris, 1748

3 Brissean: Traite de la Cataratae et du Glancoma Tornne, 1706 1892 .

Seegen Joseph: Dei Diebetus Melletus Leepsig, 1870.

Nettleship, E.: Transactions Ophthalmological Society, 1882.
B Baker, A. R.: Transactions of the Ohio State Medical Society, 1884 9 Schmidt. Rimpler: Disease of the Eye, 189 .

10 Deutschman: Untersuching zum Pathology der cataract. Arch. of Oph., 1879 .

11 Fraenkel: Lyon Medical, Lyons, 1898

12 Collins: Ophthalmic Review, 1889.

3 Roosa, St. Jobn : Diseases of the Eye, 1894

14 Risley: The University Medical Magazine, 1889

15 Thomas: Royal London Ophthalmic Hospital Reports, 1890

16 White: Journal OF the AMERICAN MEDICAL A SSOCIATION, 1802.

17 Smith Priestly: Transactions of Ophthalmologiral Soc. 188.

18 Witvalsky: Centralblatt fur Augenheilkunde, 1892.

19 Knapp, H.: Archives of Ophthalmology, 1881.

\section{THE OPERATIVE TREATMENT OF IMMATURE AND SOME FORMS OF ZONULAR} CATARACT.

Read in the Section on Ophthalmology, at the Forty-sixth Annual Meeting of the American Medical Association, held at Baltimore, Md., May $7-10,1895$.

BY JOHN E. WEEKS, M.D.

SURGEON NEW YORK EYE AND EAR INFIRMARY, PROFESSOR OF OPHTHA I. MOLOGY AND OTOLOGY, WOMAN'S MEDICAJ، COLIEGE OF THE NEW YORK INFIRMARY.

In the formation of ordinary senile cataract, the shrinkage of the nuclear portion of the lens, as has been pointed out by Becker, plays an important part. The shrinkage of the peripheral lamellæ does not progress as rapidly as those of the nuclear portion, and, as a result, a process of cleavage between peripheral and nuclear lamellæ is set up. The spaces thus formed are occupied by an emulsion known as the liquor Morgagni, which is composed of granular detritus, fat globules, myeline masses, and the intraocular fluids, and serves to produce the whitish opacities observed. The peripheral fibers themselves usually undergo degenerative changes-become filled with minute fat globules, break up into myeline masses and are sometimes entirely disintegrated. The liquor Morgagni forms between the capsule and the lens fibers, as well as between the lamellæ, serving to render the attachment between the two less intimate. At the earlier moment of this occurrence, the cataract is at the best stage for removal; however, this process is not gone through with in many cases of nuclear cataract.

In the rapidly developing cataract, particularly in relatively young individuals, the lens fibers become swollen by the imbibition of fluids and the granular degeneration of the fibers progresses very rapidly. The white soft cataract is the extreme example of this process. In these cases a stage of swelling is marked and the anterior chamber is rendered quite shallow. When the lens fibers are swollen, although they may be quite opaque, they are not readily detached from the capsule. The stage of shrinkage which follows, after it has proceeded sufficiently to permit of the presence of an anterior chamber of moderate depth, is more favorable for complete removal of the cortical portion, as some liquor Morgagni has been formed between capsule and lens. In many cases of cataract, where the process of cleavage plays a decided rôle, the stage of swelling does not develop. The nuclear lamellæ remain transparent, often are amber-hued, or show very little change, and the peripheral fibers degenerate very slowly. In still another form, occurring in older individuals, the opacity begins in the central portion of the lens, in the form of a diffuse haziness and advances slowly toward the periphery. In this form a stage of swelling seldom occurs, the lens being always smaller than the non-cataractous lens of the same age. In still another form the lens takes on a deep amber hue, all the fibers are hardened and condensed and there is 
marked haziness of the nuclear portion. In the last class of cases no liquor Morgagni forms; however, the sclerosed lens is quite easily detachable from the capsule. In the forms of rapid development the vision is much reduced at an early stage. In some cases in which the cleavage affects the equatorial portion or the posterior cortex of the lens, vision becomes reduced, but of ten remains fairly good for a number of years. In many cases of nuclear opacification and in the typical sclerosed lens, the vision may become reduced to $20-100$ or less and remain at that point for a long period of time. In the class of cases last mentioned, the patient reads with difficulty, if he reads at all, and the degree of vision is not sufficient to permit him to perform the ordinary duties of life.

There are also cases of lamellar cataract in which the opaque zone is large and dense; in some, calcareous deposits have taken place. In the process of the development of all forms of cataract there is a stage between the loss of useful vision and the formation of a condition which renders the detachment of the lens fibers from the capsule most easy, which may extend over a few months or a few years. This stage is most distressing to the individual and in not a few instances entails hardships on the patient or the patient's family.

During a long experience in the removal of the noncataractous lens, at the dead-house, conducted for self-instruction, as well as for the instruction of stu. dents in the operative surgery of the eye, the writer has studied the behavior of the cortex of the transparent lens. It was observed that in the lenses that were twenty-five or thirty years old, the nuclear por. tion was fairly firm, about two-thirds of the mass of the lens coming away with the nucleus. It was further observed that much of the detached cortex could be made to follow the nuclear portion. The firm nuclear portion became larger as the age of the lens increased. Un the strength of these observations, in spite of the dictum "hands off" in reference to operations on immature cataract, the writer began to remove the cataractous lens, soon after it had reached a degree of opaqueness sufficient to interfere with useful vision, whatever the form of the cataract might be. Before this plan was followed, the operation of ripening, advocated by Förster was tried in a number of cases, two of which are given in the following table. The lenses became rapidly opaque, but it was found that removal six weeks or two years later, was complicated by adhesion of cortical substance to the capsule, to probably the same extent as would have occurred had the extraction been performed at the time of the Förster operation. This experience was sufficient to cause the writer to abandon all ripening operations as not of sufficient value to compensate for the extra liability to accident and to inflammatory changes consequent on them. The writer now extracts at once when the opacity, whether posterior, cortical, nuclear, or peripheral or of any other form, interferes sufficiently with vision to render it of little value to the individual. If the lens is much swollen, the operation is postponed, and if the individual can wait until shrinkage occurs, without great sacrifice. If he can not, extraction is performed.

The form of operation attempted in all uncomplicated cases is-simple extraction, making the incision in the limbus and including about two-fifths of the circumference of the cornea, in individuals of 45 years or upward, and a little less in younger individ- vals. The incision is made large enough to permit of the easy extrusion of the firm nuclear portion of the lens. As much of the cortical substance as possible is removed by stroking upward over the comea with spoon or lids, or by means of Critchet's or de Wecker's spoon passed into the anterior chamber. Lavage is seldom practiced. If, during the operation, any indication for the performance of iridectomy arises, iridectomy is performed. It has been found that in the large majority of the cases, iridectomy may be avoided.

Does the cortical substance that may remain in the eye after the extraction of immature cataract give rise to inflammatory trouble? The writer has never seen it. Substances capable of producing irritation, such as tabular crystals of cholesterin or minute deposits of lime, do not exist in the cortex of the im. mature cataractous lens, but do appear in greater or less quantities in the cortex of the hyper-mature cataract and their escape from the lens capsule is not infrequently accompanied or followed by irritation to the eye, of greater or less severity. The cortex of the imnature cataract absorbs slowly if it lies in a capsule which has been opened near its periphery and in which the opening is small. If the capsule has been opened freely, which I endeavor to do, absorption of the cortical substance advances rapidly.

The accompanying table gives the results of operation in twenty-five cases in which an immature condition of the lens was present:

The twenty-five cases reported were divided as follows:

Immature soft cataract, three cases. Two occurred in the same individual and were due to extreme prostration from sea-sickness, during an ocean voyage. Förster's operation was performed before the extractions were attempted. At the time of the extractions, which followed three weeks after the Förster operation in one case and two years after in the second case, the cortical substance was still quite adberent to the capsule in both. Vision of 20-70 was eventu. ally obtained in each eye. The third occurred after gummatous iritis, during the process of which a broad posterior symechia formed; only part of the lens was opaque. About one-half of the lens substance remained in the capsule. In three months the cortex was entirely absorbed and vision of 20-20 + was obtained.

Zonular cataract, five cases. The ages of the patients were, 19 years, two; 20 years, one; 49 years, two. In two of the cases the nucleus was dense. In two cases, chalky deposits were present in the opaque zone. Mild iritis developed in one of the latter cases. In all cases some cortical lens matter remained in the capsule after the first operation. The immediate vision was $20-40$, two ; $20-100$, one ; $18-100$, one ; $1-8$, one. The ultimate vision was $20-20+$, two; $20-30$, one; $20-40$, one. All were simple extractions except one.

Immature complicated cataract, four cases. Two cases occurred as a result of heredito-specific keratoiritis and were of the diffuse variety; these were removed by the combined method (with iridectomy). The lenses which were mummified came away entirt. Ultimate vision $20-70$ in each eye. This could not he improved because of numerous macular opacities of the cornea. One case was complicated by adhe. rent leucoma due to corneal ulcer, occurring in the lower third of the cornea. Iridectomy-vision of 


\begin{tabular}{|c|c|c|c|c|c|c|c|c|c|c|}
\hline$\dot{0}$ & 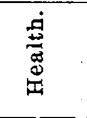 & Cataract. & $\begin{array}{l}\text { Func- } \\
\text { tional } \\
\text { Ex. }\end{array}$ & Date. & Operation. & Recovery. & 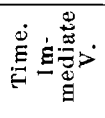 & $\begin{array}{l}\text { Secondary } \\
\text { Operation. }\end{array}$ & 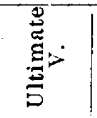 & Remarks.. \\
\hline $1 F 35$ & Feeble. & $\begin{array}{l}\text { Immature } \\
\text { soft. }\end{array}$ & Good. & $\begin{array}{l}\text { Sept } \\
2 \pi, 85\end{array}$ & $\begin{array}{l}\text { Iridectomy : cocain: } \\
\text { small incision; periph- } \\
\text { eral capsulotomy: } \\
\text { some lens cortex left in } \\
\text { capsule. }\end{array}$ & Unerentiul. & $1220-100$ & Oct. $15, ' 85$. & $20-70$ & $\begin{array}{l}\text { Förster's operatiou. } \\
\text { tugust } 3,18 \varsigma^{2} \text {. }\end{array}$ \\
\hline 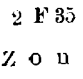 & $\begin{array}{l}\text { Feeble. } \\
\text { ular. }\end{array}$ & $\begin{array}{l}\text { Immature } \\
\text { soft. }\end{array}$ & Good. & 20, Aug. & $\begin{array}{l}\text { Iridectomy : some lens } \\
\text { cortex left in capsule. }\end{array}$ & Uneventful. & $14 \ldots$ & Sept. 10, ' 87. & $20-70$ & $\begin{array}{c}\text { Förster's operation, } \\
\text { July } 20,1887 .\end{array}$ \\
\hline 3119 & Good. & Zonular O. S. & Good. & $\begin{array}{c}\text { June } \\
\text { 15. '98. }\end{array}$ & $\begin{array}{l}\text { Cocain } 10 \text { per ceut. } \\
\text { simple: some cortex } \\
\text { remaining. }\end{array}$ & $\begin{array}{c}\text { June } 17 \text {; auterior } \\
\text { chamber restored; } \\
\text { uneventful. }\end{array}$ & $1420-40$ & $\begin{array}{l}\text { July } 25, \text { ' } 93,6 \\
\text { days. }\end{array}$ & $20-20+$ & Nuclens dense. \\
\hline $4 \mathrm{MI} 19$ & Good. & Zonular O.D. & Good. & $\underset{22,}{\text { sune }}$ & $\begin{array}{r}\text { Cocain } 4 \mathrm{p} \\
\text { simple; son } \\
\text { remain }\end{array}$ & Ineventful. & $1620-40$ & $\begin{array}{l}\text { July 25,'93; two } \\
\text { needles were }\end{array}$ & $20-20+$ & Nucleus dense. \\
\hline อ M 49 & Good. & Zonular O. S. & Good. & $\begin{array}{l}\text { July } \\
28 . ' 93 .\end{array}$ & $\begin{array}{l}\text { Corain } 4 \text { per cent. } \\
\text { simple: some cortex } \\
\text { remaining. }\end{array}$ & Eneventful. & $12 \cdot 20-100$ & $\begin{array}{l}\text { Sept.'y4: cor. } \\
\text { tical alsorbed. }\end{array}$ & $20-30$ & $\begin{array}{l}\text { Calcareous deposits } \\
\text { in nucleus. }\end{array}$ \\
\hline (i) F 20 & Good. & Zonular O.D. & Good. & $\begin{array}{l}\text { June } \\
19 .{ }^{\prime} 94 .\end{array}$ & $\begin{array}{l}\text { Cocain } 10 \text { per cent. } \\
\text { Iridectomy. }\end{array}$ & $\begin{array}{l}\text { Uneventiul; cortical } \\
\text { occluded pupil. }\end{array}$ & $131 / 8$ & July 17, '94. & $20-40$ & $\cdots \cdots$ \\
\hline $7 \mathrm{M} 49$ & Good. & $\begin{array}{l}\text { Zonular O.D. } \\
\text { Degenerated. } \\
\text { complicated. }\end{array}$ & Good. & $\begin{array}{l}\text { March } \\
5 . ' 95\end{array}$ & $\begin{array}{l}\text { Cocan } 4 \text { per cent. } \\
\text { simple: some lens } \\
\text { cortex left. }\end{array}$ & $\begin{array}{l}\text { Uneventiul until the } \\
\text { sixth day, when a low } \\
\text { form of iritis occurred. }\end{array}$ & $191 \ll-200$ & $\begin{array}{l}\text { Aug. } 7 \text { : cortex } \\
\text { absorbed. }\end{array}$ & $20-50$ & $\begin{array}{l}\text { Calcareous deposits } \\
\text { in nucleus. Their } \\
\text { escape undoubtedly } \\
\text { produced the iritis. }\end{array}$ \\
\hline $8 M 17$ & Good. & $\begin{array}{l}\text { Diffuse } 0 . \mathrm{s} \text {. } \\
\text { after specific } \\
\text { kerato iritis. }\end{array}$ & Good. & $\begin{array}{l}\text { Oct. } \\
22 . ' 95 .\end{array}$ & $\begin{array}{l}\text { Ether.large iridectomy, } \\
\text { pupillary membrabe } \\
\text { removed with capsule } \\
\text { foreeps and excised; } \\
\text { mummified lens } \\
\text { removed entire; lost a } \\
\text { few drops of vitreous. }\end{array}$ & Uneventful. & $1412-200$ & $\begin{array}{l}\text { Noy } 26 \text {; sealed } \\
\text { with cilutery. }\end{array}$ & $20-70$ & $\begin{array}{l}\text { Cornea large with } \\
\text { numerous macular. }\end{array}$ \\
\hline $9 \mathrm{M} 17$ & Good. & $\begin{array}{l}\text { Diffuse } 0 . \text { D. } \\
\text { as in No. } 8 \text {. }\end{array}$ & Good. & $\begin{array}{l}\text { Jan. } \\
7 . ' 98 .\end{array}$ & $\begin{array}{l}\text { Cocain } 10 \text { per cent:; } \\
\text { large iridectomy: } \\
\text { mummified lens re- } \\
\text { moved entire ;pupillary } \\
\text { membrane removed. }\end{array}$ & Uneventful. & $1515-200$ & $\begin{array}{l}\text { Feb. } 11 \text {; } \\
\text { wound sealed } \\
\text { with cautery. }\end{array}$ & $20-70$ & $\begin{array}{l}\text { Dense pupillary } \\
\text { membrane. }\end{array}$ \\
\hline $10 \mathrm{M} 75$ & Good. & $\begin{array}{c}\text { O.S. } \\
\text { Immature } \\
\text { V. }=13-200 .\end{array}$ & Grood & $\begin{array}{l}\text { March } \\
29 . ' 93 .\end{array}$ & $\begin{array}{l}\text { Cocain } 10 \text { per cent. } \\
\text { Iridectomy. }\end{array}$ & Uneventiul. & โ2 20-70 & $\cdots \cdots$ & $20-70$ & $\begin{array}{c}\text { Adherent leucoma } \\
\text { in lower third of } \\
\text { cornea,after cormeal } \\
\text { ulcer. }\end{array}$ \\
\hline 11.38 & Good. & $\begin{array}{l}\text { Immature } \\
\text { traumatic O.D. }\end{array}$ & Good. & $\begin{array}{l}\text { June } \\
5 . ' 94 .\end{array}$ & $\begin{array}{l}\text { Cocain } 10 \text { per cent. } \\
\text { simple; some lens sub- } \\
\text { stance remained. }\end{array}$ & $\begin{array}{l}\text { Uneventful; consider- } \\
\text { able soft lens matter } \\
\text { in pupil. }\end{array}$ & $-111 / 4$ & Refused. & $20-40$ & $\begin{array}{l}\text { Lens cortex } \\
\text { absorbed. }\end{array}$ \\
\hline 12 F 71 & Good. & $\begin{array}{l}\text { Post cortical } \\
\text { Cat. V. }=20-200 \\
\text { O. S. }\end{array}$ & Good. & $\begin{array}{c}\text { May } \\
17, \text { '93. }\end{array}$ & $\begin{array}{l}\text { Simple, cocain } 10 \text { per } \\
\text { cent.: a little cortex } \\
\text { left in capsule. }\end{array}$ & Uneventiul. & $12 \cdot 20-30$ & $\begin{array}{l}\text { In we } 8 \text {; cortex } \\
\text { had become } \\
\text { absorbed. }\end{array}$ & $20-20$ & $\cdots \cdot \cdot \cdot \cdot$ \\
\hline $13 \mathrm{M} 54$ & Good. & $\begin{array}{c}\text { Immature } \\
\text { Seniie, } \\
\text { V. }=20100 \text { U. I). } \\
\text { Ant. cham. } \\
2 / s \text { normal. }\end{array}$ & Good. & $\begin{array}{l}\text { March } \\
13.91 .\end{array}$ & $\begin{array}{l}\text { Cocain } 10 \text { per cent. } \\
\text { simple; very little cap- } \\
\text { sule remaining. }\end{array}$ & Eneventiul. & $1420-20$ & $\begin{array}{c}\text { Apr.23; cortex } \\
\text { had become } \\
\text { absorbed. }\end{array}$ & $20-20+$ & $\begin{array}{l}\text { Patient had been } \\
\text { out of employment } \\
\text { one year and was } \\
\text { advised to wait an- } \\
\text { other year because } \\
\text { of clear cortex }\end{array}$ \\
\hline 14 M 54 & Good. & $\begin{array}{c}\text { Immature } \\
\text { Senile } \\
\text { O. S. } \\
\text { V. }=20-100\end{array}$ & Good. & $\begin{array}{l}\text { March } \\
20,94 .\end{array}$ & $\begin{array}{l}\text { Cocain } 10 \text { per rent. } \\
\text { simple: very little cor- } \\
\text { tex remained. }\end{array}$ & Uneventful. & $1420-20$ & $\begin{array}{l}\text { Apr. } 23 \text {; cortex } \\
\text { absorbed. }\end{array}$ & $20-20+$ & Nuclear cataracts. \\
\hline $15 \mathrm{M} 31$ & Good. & $\begin{array}{l}\text { O. S. Soft, } \\
\text { traumatic } \\
\text { partly opaque, } \\
\text { Ant. chum. } \\
2 / 3 \text { normal. }\end{array}$ & Good. & $\begin{array}{l}\text { May } \\
1, \text { '94. }\end{array}$ & $\begin{array}{l}\text { Cocain } 10 \text { per cent. } \\
\text { simple; incision } 1 / 3 \\
\text { cornea; about half of } \\
\text { the lens substance } \\
\text { remained. }\end{array}$ & Uneventful. & $12 \quad 4-200$ & $\begin{array}{c}\text { July } 30 ; \text { cortex } \\
\text { almost } \\
\text { entirely ab- } \\
\text { sorbed. }\end{array}$ & $20-20+$ & $\begin{array}{l}\text { Cataract due to } \\
\text { gummatous iritis. }\end{array}$ \\
\hline $16 \mathrm{M} 64$ & Good. & $\begin{array}{l}\text { Traumatic } \\
\text { Senile, } \\
\text { Ant. cham. } \\
\text { very shallow. }\end{array}$ & Good. & $\begin{array}{c}\text { Muy } \\
15 . ' 94 .\end{array}$ & $\begin{array}{l}\text { Cocain } 10 \text { per cent. } \\
\text { simple; incision very } \\
\text { small, enlarged with } \\
\text { scissors. }\end{array}$ & Uneventful. & $2020-50$ & No decision. & $\begin{array}{l}\text { Nov. } 6 \\
20-20 \\
294\end{array}$ & $\begin{array}{l}\text { V. }=20-20 \\
\text { April } 6,{ }^{\prime} 95 .\end{array}$ \\
\hline 17 M 57 & Good. & $\begin{array}{l}\text { Immature } \\
\text { Diabetic. }\end{array}$ & Good. & $\stackrel{\text { May }}{15, \underbrace{}_{94}}$ & $\begin{array}{l}\text { Cocain } 10 \text { per cent. } \\
\text { simple; very little cor- } \\
\text { tex remained in the } \\
\text { capsule. }\end{array}$ & Uneventful. & $11 \cdot 20-50$ & Juve 26. & $20-20+$ & - . . . . . . . \\
\hline $18 \mathrm{M} 50$ & Good. & $\begin{array}{l}\text { Immature } \\
\text { Sevile. }\end{array}$ & $\begin{array}{l}\text { (xood. } \\
200\end{array}$ & $\begin{array}{c}\text { April } \\
25, ' 94 .\end{array}$ & $\begin{array}{l}\text { Cocain } 10 \text { per cent. } \\
\text { simple: some cortex } \\
\text { remained. }\end{array}$ & Uneventful. & $020-50$ & May 19. & $20-20$ & . . . . . . . \\
\hline $19 \mathrm{M} 67$ & Good. & $\begin{array}{l}\text { Immature } \\
\text { Senile. }\end{array}$ & $\begin{array}{l}\text { Good. } \\
\text { V. }=10 \text {. } \\
200\end{array}$ & $\begin{array}{l}\text { July } \\
3, \text {, } 94 .\end{array}$ & $\begin{array}{l}\text { Cocain } 10 \text { per cent. } \\
\text { simple; some cortex } \\
\text { remained. }\end{array}$ & Uneveutful. & $1220-50$ & Aug. 8, '94. & $20-30$ & 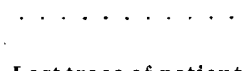 \\
\hline 20 II 43 & Good. & $\begin{array}{l}\text { Immature } \\
\text { Senile. }\end{array}$ & Good. & $\begin{array}{l}\text { Aug. } \\
30, \text { '.91. }\end{array}$ & $\begin{array}{l}\text { Cocain } 10 \text { per cent. } \\
\text { simple. }\end{array}$ & $\begin{array}{c}\text { August } 31 \text {; prolapse of } \\
\text { iris; excised. }\end{array}$ & $1220-50$ & 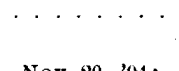 & $20-50$ & $\begin{array}{c}\text { Lost trace of patient } \\
\text { after the primary } \\
\text { operation. }\end{array}$ \\
\hline $21 \mathrm{M} 69$ & Good. & $\begin{array}{l}\text { Immature } \\
\text { Senile. }\end{array}$ & Good. & $\begin{array}{l}\text { Oct. } \\
30,{ }^{\prime} 94 .\end{array}$ & $\begin{array}{l}\text { Cocain } 10 \text { per cent. } \\
\text { simple: some cortex } \\
\text { remained in capsule. }\end{array}$ & Uneventful. & $1220-40$ & $\begin{array}{l}\text { Nov. } 20, ' 94: \\
\text { lens cortex } \\
\text { absorbed. }\end{array}$ & $20-20+$ & - . . . . . . . \\
\hline $22 \mathrm{M} 67$ & Good. & $\begin{array}{l}\text { Immature } \\
\text { Senile. }\end{array}$ & $\begin{array}{l}\text { Good. } \\
\mathrm{V}=1 .=15\end{array}$ & $\begin{array}{l}\text { March. } \\
5,95 .\end{array}$ & $\begin{array}{l}\text { Cocain } 10 \text { per cent. } \\
\text { simple; some lens cor. } \\
\text { tex remained. }\end{array}$ & Uueveutful. & $1316-200$ & 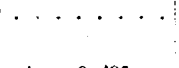 & $20-40$ & ....... \\
\hline $23 \mathbf{M ~} 51$ & $\begin{array}{l}\text { Alco- } \\
\text { holle. }\end{array}$ & $\begin{array}{c}\text { Immiture } \\
\text { Senile. }\end{array}$ & $\begin{array}{l}\text { Good. } \\
\text { V. }=12 \\
200\end{array}$ & $\begin{array}{l}\text { March } \\
11,95 .\end{array}$ & $\begin{array}{l}\text { Cocain } 4 \text { per ceut. } \\
\text { simple; some lens cor. } \\
\text { tex remained. }\end{array}$ & Uneventful. & $12 \cdot 20-10$ & Apr. 9, '95. & $20-15$ & $\begin{array}{l}\text { Lens cortex com- } \\
\text { pletely absorbed. }\end{array}$ \\
\hline & Good. & $\begin{array}{l}\text { Immature } \\
\text { senile } \\
\text { Nuclear. }\end{array}$ & $\begin{array}{l}\text { Good. } \\
\mathrm{V}_{200}=18\end{array}$ & $\begin{array}{l}\text { March } \\
19 ., 95 .\end{array}$ & $\begin{array}{l}\text { Cocain } 4 \text { per cent. } \\
\text { simple; some lens cor- } \\
\text { tex remained. }\end{array}$ & Uneventful. & $1720-40$ & Apr. 23, '95. & $20-20+$ & $\begin{array}{l}\text { Leus cortex } \\
\text { absorbed. }\end{array}$ \\
\hline & Good. & $\begin{array}{l}\text { Immature } \\
\text { Seuile, } \\
\text { Nuclear. }\end{array}$ & $\begin{array}{l}\text { Good. } \\
20-100\end{array}$ & $\begin{array}{l}\text { March } \\
26,95\end{array}$ & $\begin{array}{l}\text { Cocain } 4 \text { per cent. } \\
\text { simple. }\end{array}$ & Uneventful. & $1720-50$ & A pr. 27, '95. & $20-20+$ & 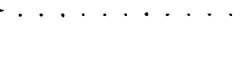 \\
\hline
\end{tabular}

20-70 was obtained. One case was that of an imma- Immature diabetic cataract, one case. The extracture traumatic cataract following a blow on the eye. tion, after the simple method, was not accompanied A simple extraction was performed. Vision of $20-40$ with difficulties. Vision of $20-20+$ was obtained. was obtained. Posterior cortical cataract, one case. There were twelve cases of ordinary senile cataract, Simple extraction was performed. But very little four of which were of the diffuse nuclear variety difficulty was experienced in freeing the eye of the which develops very slowly. Simple extraction was greater portion of the cortical substance. Vision of performed in all and was not accompanied with un. $20-20$ was obtained. usual difficulty. Some cortical substance remained in 
almost all cases, but was absorbed almost if not en. tirely in a few weeks, giving no trouble. No iritis occurred in these cases. Prolapse occurred in one case only and was probably due to traumatism. The healing in these cases was uneventful and the vision eventually obtained was extremely satisfactory. The immediate vision was $20-20-$ two ; 20-30, one; $20-40$, three; 20-50, six; $16-200$, one; 4-200, one.

The ultimate vision after discission in twelve cases: $20-15$, one : $20-20+$, six ; $20-20$, two ; 20-30, one ; $20-$ 40 , one ; $20-50$, two.

In the twenty-five cases there were no losses. Iridectomy was done in six cases. Simple extraction in nineteen cases. One prolapse occurred. Discisgion was done in twenty cases.

The ultimate visual results were as follows: 2020 or better, thirteen ; $20-30$, two ; 20-40, three; 2050 , two; 20-70, five. The youngest patient operated upon was 17 years, the oldest, 75 years. The mean, $45 \frac{1}{4}$ years. In all cases the remaining cortex absorbed almost, if not entirely, either before or after discission was performed.

The results appear to the writer to be as favorable as those obtained by the removal of cataract ordinarily, at the stage of maturity, and the relief to the patient was in many cases very great, saving them one, two, or even more years of idle waiting.

The difficulty of removing immature cataract is greater than that of removing mature cataract and should be done by expert operators. In the hands of expert operators the danger is little more than where the lens is ripe.

154 Madison Avenue.

DISCLSSION ON PAPERS OF DRS. BAKER AND WEEKS.

Dr George E. Frothingham, Detroit, Mich.-In regard to the paper of Dr. Baker I will say that I agree in the main with the views of the author. While $I$ think it is the experience of most of us that any considerable opacity of the lens never fully clears up, slight opacities may nearly disappear; and we find commeneing cataract at times due to change of nutrition of the lens, dependent upon disease of the choroid or some constitutional disease, that may be relieved. and with the effect to retard or arrest the development of the cataract. I remember one case in my practice in which the development of a cataract evidently due to choroiditis has apparently been arrested; at any rate it has made no progress for about seven years. With the conclusions in Dr. Baker's paper, I fully agree. They are in accordance with the general principles that in incipient cataract we should make a careful and thorough examination of the eye and of the general condition of the patient and remedy any pathologic conditions so far as we can.

In regard to the paper of Dr. Weeks, it deals with a most important subject. Fortunately we are not often called upon to hasten the maturity of the cataract. In some cases however, where both eyes are about equally affected and advance very slowly and the condition of the patient will not allow of waiting for the natural process of ripening, we are forced to decide between extracting an immature cataract or attempting to hasten the maturity by some operation. Of the various operations that have been devised I think that Förster's is the best and safest. Although it will sometimes fail to hasten the progress of development, it is attended with very little danger. It will lead to iritis in a certain per cent. of cases but the worst result I have ever seen was a slight synechia. The pupil should be kept well dilated after the operation until all danger has past. If the operation fails to hasten maturity it will allow of the extraction of the immature cataract with the greatest possible degree of safety. If I were the most ardent advocate of simple extraction, I would make an exception in the case of immature cataract. I make in all cases a preliminary iridectomy, and after all irritation has completely subsided and the eye has perfectly recovered from the effect of the operation, if it has failed to produce ripening of the cataract, I then extract the immature cataract, making a peripheral incision in the cap- sule as a still further safeguard against dangerous reaction rom any lens matter that may remain in the eye.

Dr. HERMAN KNAP', New York-As to heat producing cataract, I know of one case where I produced a cataract by the galvano-cautery point with which I burned off the apex of a keratoconus too cautiously, i.e., too slowly pierced the cornea. l wanted to make only a very small puncture in the cornea. I obtained this end, but a slowly developing yellowish cataract was the result and had to be extracted. Whether vutward heat for instance, in fireworkers, is a notable factor in the development of cataract, I am not prepared to say. About thirty years ago, I saw a lens of a diabetic patient rather quickly become opaque and soon after elear up. The observation though not fully accurate has remained vivid in my mind, and ever since that time I have watched the progress or regress of cataract, but the above example has remained the only one, end therefore has no appreciable value. Unripe cataracts not intrequently place us in the alternative of removing a cataract prior to the time when the patient's chances of a good recovery are greatest, or to let a patient wait an indefinite length of time for that most favorable period. The vogue in to which the ripening operations have come is thus easily accounted for. They would be a godsend if their action were certain and free from danger. Uufortunately many an operation for ripening has been done without producing any effect; on the other hand, these operations have proved injurious by provoking iritis and its consequences, and some by a degree of deleterious morbid process (plastic and purulent irido-cyclitis and panopthalmitis). Even if these mild or severe reactions occur only exceptionally, we are mortified to have created by our own hands any conditions that dim by complications the chances of the patient, when the chief operation, the extraction, has to be undertaken. I, for my part, thus prefer the risk of dealing with remnants by a secondary discission, to the double operation of ripening and extracting the lens which in a majority of cases requires a subsequent division also to clear the pupil.

Dr. Joseph A. White, Richmond, Va.-In regard to Dr. Baker's paper on the etiology of cataract, I am satisfied that the explanation of Dr. Risley, attributing the opacification of the lens to disturbance of its nutrition by pathologic processes in the uvea, especially the choroid, is correct in a large number of cases, while not generally applicable. All of you, as well as I, have examined many cases of cataract after extraction where there was no choroidal disease nor any other evidence of a pathologic process inside the eye. and consequently I am satisfied that there are many cases of cataract in which the etiology is to us an undiscovered factor, and that much yet remains to be found out in regard to this subject. Why in one person an opacification of the lens remains stationary and in another is progressive, is also a question yet to be solved. That this is true we well know for in zonular cataract we have it progressive in one, and stationary in anotber case. Why can not therefore, opacification of the lens remain stationary in adults? I know of a case of a young man who received a blow in the eye several years ago, which by contra coup without wound of the cornea ruptured the iris at its pupillary edge and also the capsule of the lens in direct line with the iritic wound. A small opacity of the lens developed at this point and to this day remains stationary. Cataract has not followed nor has the opacity disappeared. As to the disappearance of lenticular opacities, I have had very little experience, my only case being the one referred to by Dr. Baker. This case was one with marked anterior central opacity of the lens sufficient to materially decrease vision, and cause a semi-blindness with a contracted pupil. He wished to have the cataract removed and submitted to the ripening process of paracentesis and external massage with great hopes of having a ripe cataract in a few weeks. His next visit showed a decided diminution in the size of the opacity. I triturated the eye again. Result. three weeks later, a perfectly clear lens. Now either this opacity of the lens disappeared or I made a mistake, but every precaution against an error had been taken. The pupil was gray when it was contracted and there was no ophthalmoscopic reflex with dilated pupil; the fundus was illuminated around the opacity and the vitreous was clear. The opacity moved up and down, with the eye locating it either in the anterior part of the lens or the cornea, and it certainly was not in the latter; hence I concluded that it was a case of partial opacification of the lens that had cleared up; how or why, I don't know; what the massage had to do with the result I am unable to say. Like cataract, it may come to a standstill or it may even retro- 
grade toward recovery, although such cases are rare. To discuss Dr. Weeks' paper would take more time than is allowed me. I have already, however, gone on record to some extent in regard to immature cataract. I presented to this body a paper on that subject several years ago in which $I$ suggested the adoption of a simple process of ripening immature cataracts by paracentesis and external massage without iridectomy, because I had had bad results in Förster's operation from iritic processes. I reported a number of cases then and have done others since, and have had exceptionally good results-no bad ones. I have been lucky, I suppose. Like Dr. Knapp, I think the less traumatism an eye is subjected to the better, and hence I never ripen an immature cataract if the case will wait for nature's processes, and then only if the patient is under 60 years of age, because $I$ thereby break up and loosen the cortex from the capsule, simplifying the extraction. Over 60 years of age, I extract without waiting for maturity, but it is difficult to say what the latter signifies, as it does not mean the same to each one of us. For instance, a patient may be too blind to move about with assistance, and the cataract be still immature; and again sight enough to see large letters may be present, and the cataract be perfectly ripe, This especially applies to those amber-tinted cataracts in old people which never become perfectly opaque and hence relatively are immature, while in reality they are perfectly ready for extraction.

Dr. J. I. Trompson, Indianapolis--I wish to say that I have seen a well-marked unmistakable case of cataract disappear spontaneously. I had every opportunity of watching it for years before and several years also after the clearing up of the lens. As I have published the case with all of it s complications, I shall only add that this case of spontaneous cure of a cataract by liquid degeneration within the capsule was more clear to me than is the well.known fact that this world of ours revolves upon its axis.

Dr. Jayes A. Irdston, Chicago-A few points bearing on the subject matter as presented in the paper, suggested themselves as the paper was read and discussed: I believe that we go a little too far in assuming in all cases in which lenticular opacities disappear, that we have a true cataractous formation, for we know that cataract exhibits a process peculiar alone to itself during the formation stage and, indeed, one that is quite characteristic. Becker has done more to enhance our knowledge with respect to cataract than any other investigator in this line, and he has shown that primarily cataract develops by the formation of vacuoles as little air chambers distributed through the lens structure and that these subsequently become filled with fluid of a different density from the remaining lens substance, and finally, there is a separation of the nuclear and cortical portions of the lens from the lenticular capsule constituting light cataract. Now in many instances in which lenticular opacities disappear spontaneously, it seems that we are not confronted by a true cataractous formation. Still we have opacities occurring in cases in which the capsule has been punctured and subsequently closes. Here we may have spontaneous disappearance. But I seriously doubt the propriety of accepting the statement that any form of diabetic cataract ever spontaneously disappears, as we know such changes only assert themselves in the later stages of diabetes when our case is almost beyond redemption. We have cataract arising from large doses of naphthalin or ergot and those arising from concussion, etc., and it seems that possibly these are the types of cataract, erroneously so called, which are capable of spontaneously disappearing and which are all grouped under the heading of incipient cataract.

Dr. F. C. Hotz, Chicago-My experience with the ripening processes of immature cataracts has not been satisfactory. In some cases no change in the lens was produced; in a number of cases the manipulation was followed by more or less decided cyclitic irritation. I have many years since given up all attempts at ripening, and have not felt induced to return to the attempt even by the favorable report $\mathrm{Dr}$. White gave of his cases at the Detroit meeting. As to the extraction of immature cataract, I find the operation does not involve greater danger than the removal of a fully mature cataract, provided there is not a very large amount of absolutely transparent lens matter. But where this is the case the patient's vision is usually still so good that there exists no urgency for an operation. In the slowly progressing opacification which starts in the cortex and therefore early causes great disturbance of sight the lens seldom, if ever, becomes absolutely opaque. It appears quite opaque at focal illumination but proves transparent for the ophthalmoscope so that the fundus can be seen although through a mist. In this form of cataract the whole lens is a piece of yellowish jelly and it comes out in toto, leaves a clear pupil and the healing is as smooth as after the extraction of a ripe cataract.

DR. S. D. Risley, Philadelphia-Dr. Baker has very courteously noticed my published observations regarding the etiology and treatment of incipient cataract. I rise to call attention to a single point in which he has failed to interpret quite correctly some ambiguous sentence in my paper on the subject. While in the eighty cases of incipient cataract there reported, it seemed the treatment addressed to the choroidal disease had arrested the progress of the opacification of the lens. I think it is stated there that in no case had I witnessed the disappearance of opacities already formed.

Dr. A. J. Erwin, Mansfield,Ohio-At the Detroit meeting in 1892, I read a paper on this subject, in which I brought forward ten cases that I had treated in periods of from four to ten years previous to that time, in which there had been no increase of the opacity from the time treatment was begun. Since then, one-half of those cases have died, and none of them required an operation of any kind for cataract during life. Four are living and under my observation; one has disappeared. In these four cases no increase of opacity has occurred as yet. In one-half of the cases there was at least one opaque lens-mature cataract. I think that some of them belong to that class of cases that never will mature. There was not much improvement although some amount of vision in nearly every case, but there appeared to be a complete stopping of the advancement of the opacity. My treatment as I gave it on that occasion was iron tonics, with cleansing and iodin applications about the eye. I have made up my mind since that the application of weak solutions of iodin applied daily in some cases is the most important part of the treatment, and that the best solution is that of about one-half the strength of the officinal tincture.

Dr. Dudiey S. ReYNolds, Louisville, Kg.-It is unfortunate that gentlemen who speak of stationary opacities of the lens fail to state more definitely the character and precise location of those areas of opacity. We are all familiar with the peripheral opacities of the lens observed in childhood and remaining nearly stationary through life to advanced age. Traumatic opacities of the lens often remain distinctly circumscribed for years. I have in mind the case of a student who has a foreign body encysted in the upper portion of the lens, midway between the periphery and the vertex, and which has remained more than four years without any disposition to increased opacity beyond the small area of the wounded portion.

Dr. J. E. Wreks, New York--I am glad to hear the expressions given against the artificial methods of ripening cataracts. I think it will not be long before such methods will be entirely abandoned.

\section{PRACTICAL POINTS IN ANESTHESIA FOR} PLASTIC OPERATIONS ABOUT THE EYE.

Read in the Section on Ophthalmology, at the Forty-sixth Annual Meeting of the American Medical Association

, May 7-10,1895.

BY M. W. ZIMMERMAN, M.D.

PHILADELPHIA, PA.

A perfect anesthetic would render the patient completely insensible to pain, without in the slightest degree endangering his life. Unfortunately this has not been discovered, and we must select that which best meets the requirements of the particular operation to be performed. I shall avoid entirely discussing the broad subject of anesthesia with its relations to surgery in general, and confine myself to some of the practical problems presented by operations about the eye.

Those plastic operations which come within the scope of the ophthalmic surgeon involve tissues controlled by the very mobile facial muscles, and it is desirable to avoid the disturbance of relation which would result from their activity.

Again, operations of this class, for cosmetic reasons, and because they usually have for their object 